\title{
Hubungan Risiko Tsunami terhadap Tingkat Ansietas pada Anak-anak di SDN 02 Ulak Karang Selatan (Zona Merah) dan SDN 33 Kalumbuk (Zona Hijau)
}

\author{
Septia Endike ${ }^{1}$, Yaslinda Yaunin ${ }^{2}$, Rima Semiarty $^{3}$
}

\begin{abstract}
Abstrak
Padang adalah salah satu kota di Indonesia yang rawan terhadap kejadian gempa dan Tsunami. Orang yang selamat dari peristiwa Tsunami bukan hanya menderita bencana yang sifatnya fisik dan harta benda saja, tetapi lebih pada trauma mental yang tidak mudah dilupakan. Trauma mental itu sendiri bila tidak ditangani dengan sungguhsungguh dan profesional dapat berlanjut pada gangguan jiwa salah satunya adalah ansietas. Tujuan penelitian ini adalah untuk mengetahui hubungan risiko tsunami terhadap tingkat ansietas pada anak sekolah dasar di zona merah dan hijau Kota Padang. Penelitian analitik observasional ini menggunakan desain cross-sectional dengan jumlah subjek sebanyak 117 responden yang dipilih secara stratified random sampling di SDN 02 Ulak Karang Selatan (zona merah) dan SDN 33 Kalumbuk (zona hijau). Data dikumpulkan melalui wawancara responden menggunakan kuesioner HRS-A yang kemudian dianalisis menggunakan uji chi-square. Hasil penelitian menunjukkan tingkat ansietas pada anak-anak yang bersekolah di zona merah yaitu 7 anak (14\%) ringan, 8 anak (16\%) sedang dan 1 anak (2\%) berat, sedangkan di zona hijau didapatkan 16 anak $(23,9 \%)$ ringan, 8 anak $(11,9 \%)$ sedang dan tidak ada anak yang mengalami ansietas berat. Berbagai simulasi gempa dan Tsunami yang dilakukan terhadap anak sekolah di zona merah menurunkan angka ansietas pada anak tersebut. Hasil uji chi-square menunjukkan bahwa nilai $p=0,151$ ( $p<$ $0,05)$ yang artinya tidak ada hubungan yang bermakna antara risiko tsunami terhadap tingkat ansietas pada pada anak-anak di zona merah dan zona hijau.
\end{abstract}

Kata kunci: ansietas, tsunami, anak

\section{Abstract}

Padang is one of the city in Indonesia that have a high risk to tsunami disaster. For those who survived at the tsunami attack, it is not only a physical and property damage, but rather on the mental trauma that is not easily forgotten and can lead to mental disorders such as anxiety. The objective of this study was to examined the correlation of the tsunami risk to the anxiety level on children in the red and green zone of Padang.This research was an observational analytic study using cross-sectional design with a total sample of 117 respondents were selected by stratified random sampling in SDN 02 Ulak Karang Selatan (red zone) and SDN 33 Kalumbuk (green zone). Data were collected through interviewing respondents using a HRS-A questionnaire, then analyzed with chi-square test. The results of this study indicate the level of anxiety in children who attend school in the red zone as many as 7 (14\%) mild, $8(16 \%)$ moderate and 1 (2\%) severe, whereas the green zone obtained in 16 (23, 9\%) mild, 8 (11.9\%) moderate, and no child is experiencing severe anxiety. Additional findings indicate that a variety of simulated earthquake and tsunami were conducted on the red zoned school children decrease the anxiety in the child. The results of chi-square test showed that the $p$ value $=0.151$ ( $p$ <.05), which means there is no significant association between the risk of a tsunami on the level of anxiety in children at red zone and green zone.

Keywords: anxiety, tsunami, children 
Affiliasi penulis: 1. Pendidikan Dokter FK UNAND (Fakultas Kedokteran Universitas Andalas Padang), 2. Bagian Psikiatri FK UNAND, 3. Bagian IImu Kesehatan Masyarakat FK UNAND

Korespondensi: Septia Endike, email: Khe_dee@yahoo.com ,

Telp: 085274632486

\section{PENDAHULUAN}

Tsunami berasal dari bahasa Jepang, terbentuk dari kata tsu yang berarti pelabuhan dan nami yang berarti gelombang. Berdasarkan terminologi, pengertian tsunami adalah gelombang laut yang terjadi karena adanya gangguan impulsif pada laut. Gangguan impulsif tersebut terjadi akibat adanya perubahan bentuk dasar laut secara tiba-tiba dalam arah vertikal atau dalam arah horizontal. Perubahan tersebut disebabkan oleh tiga sumber utama, yaitu gempa tektonik, letusan gunung api, atau longsoran yang terjadi di dasar laut. ${ }^{1}$

Indonesia merupakan negara yang rawan terhadap tsunami, terutama kepulauan yang berhadapan langsung dengan pertemuan lempeng Eurasia, Indo-Australia dan Pasifik, antara lain bagian Barat Sumatera, Selatan Jawa, Nusa Tenggara, bagian Utara Papua, Sulawesi dan Maluku, serta bagian Timur Kalimantan. Dalam 37 tahun terakhir terjadi lebih dari 10 kali kejadian tsunami di berbagai tempat di Indonesia dan dalam satu abad terakhir terjadi 3 kali kejadian Tsunami yang menelan banyak korban jiwa. Bagi mereka yang selamat, peristiwa bencana alam itu bukan merupakan bencana yang sifatnya fisik dan harta benda saja, tetapi lebih pada trauma mental yang tidak mudah dilupakan. Pada umumnya masyarakat dan pemerintah dalam menyikapi korban berbagai macam peristiwa, lebih menitik-beratkan pada aspek yang sifatnya fisik; misalnya bantuan pengobatan, sandang, pangan dan papan. Aspek kejiwaan/mental/psikologik yang mengarah pada gangguan stress pasca trauma kurang diperhatikan. Stress pasca trauma itu sendiri bila tidak ditangani dengan sungguh-sungguh dan profesional dapat berlanjut pada gangguan jiwa seperti kecemasan, depresi, psikosis (gangguan jiwa berat) bahkan sampai pada tindakan bunuh diri. ${ }^{2}$

Kecemasan (ansietas) adalah suatu respon normal individu terhadap pertumbuhan, perubahan, pengalaman baru, penemuan identitas dan makna hidup. Ansietas muncul dengan gejala pusing, rasa melayang, hiperhidrosis, diare, hiperrefleksi, hipertensi, palpitasi, pupil midriasis, gelisah, sinkop (pingsan), takikardia (denyut jantung cepat), rasa gatal, tremor dan gangguan lambung. Pada ansietas patologik, etiologinya tidak dapat ditelusuri dan menimbulkan hendaya dalam fungsi sosial dan pekerjaan. Ansietas patologik merupakan sesuatu yang sangat mengganggu bagi penderita yang mengalaminya, sehingga hal demikian perlu mendapat perhatian. Ansietas (kecemasan) adalah rasa ketakutan yang difus, tidak menyenangkan dan samarsamar terhadap sesuatu yang tidak jelas (belum pernah terjadi). Selama individu masih dapat mengatasi stresor yang ada, maka ansietas tersebut masih bersifat normal. Jika individu tidak mampu mengatasi stresornya, maka akan timbul ansietas patologik yang merupakan respons terhadap ancaman yang sumbernya tidak diketahui, bersifat internal, samar-samar atau konfliktual. $^{2}$

Ada beberapa hal yang mempengaruhi tingkat ansietas pada individu, beberapa diantaranya adalah maturitas individu, tipe kepribadian dan pendidikan. Individu yang memiliki kepribadian matang akan lebih sukar mengalami gangguan akibat stress, sebab mempunyai daya adaptasi yang besar terhadap stressor yang timbul. Sebaliknya individu yang mempunyai kepribadian tidak matang yaitu yang tergantung pada kepekaan terhadap ransangan sehingga sangat mudah mengalami gangguan akibat stress. $^{3}$

Berbagai penelitian dalam beberapa tahun terakhir telah dilakukan untuk membuktikan terjadinya gangguan psikiatri (kriteria DSM IV) pada korban bencana alam. Salah satu contohnya adalah penelitian yang dilakukan pada tahun 2010 terhadap korban gempa bumi Haiti yang menunjukkan bahwa 55\% subjek mengalami gejala depresi dan $40 \%$ gejala ansietas. $^{4}$

Penelitian di Indonesia terhadap anak-anak korban tsunami yang berada di desa Krueng Anoi Kecamatan Kota Baro Aceh Besar Nangroe Aceh Darussalam pada tahun 2006 yang menunjukkan kurang dari 10\% anak-anak menunjukkan gejala PTSD. ${ }^{5}$ Selain itu, dari penelitian terhadap kesehatan psikis di Sumatra setelah Tsunami ditunjukkan bahwa ada perbedaan kesehatan psikis setelah kejadian bencana pada 
masyarakat di daerah dengan kerusakan berat dibandingkan dengan masyarakat di daerah yang tidak secara langsung terkena Tsunami. ${ }^{6}$

Hasil survei awal di SDN 21 Purus didapatkan bahwa banyak orang tua murid yang memilih untuk memindahkan anak mereka ke sekolah lain setelah kejadian gempa 2009 silam, sehingga terjadi penurunan jumlah siswa dalam 4 tahun terakhir, yang menunjukkan bahwa ada kecemasan pada murid ataupun orang tua murid akibat kejadian gempa 2009 tersebut.

Berdasarkan hasil penelitian dan survei awal tersebut di atas perlu dilakukan suatu penelitian pada kelompok masyarakat khususnya anak-anak di zona merah dan zona hijau Kota Padang untuk mengetahui adanya perbedaan tingkat ansietas terhadap risiko tsunami pada anak-anak sekolah dasar, mengingat adanya perkiraan ahli tentang akan terjadinya megathrust di Pantai Barat Sumatera dengan kekuatan jauh lebih besar dari yang pernah terjadi dan juga berbagai informasi dari media tentang perkiraan timbulnya bencana tsunami setelah gempa dahsyat yang terjadi pada 30 September 2009 silam. $^{7}$ Alasan pemilihan subjek penelitian siswa-siswi kelas 4 dan 5 SD adalah: (1) Siswa-siswi tersebut belum dihadapkan dengan stres menghadapi Ujian Nasional yang akan membuat rancu hasil penelitian; (2) Siswa-siswi tersebut dianggap sudah dapat mengerti akan ancaman yang terjadi di sekitarnya.

\section{METODE}

Penelitian ini menggunakan metode eksperimental kuasi dilakukan sejak Agustus 2013Maret 2014 di RS Dr. M. Djamil. Populasi pada penelitian ini berjumlah 120 orang. Sampel yang digunakan sebanyak 55 orang yang memenuhi kriteria inklusi

\section{HASIL}

Karakteristik pasien yang menjadi subjek penelitian ditampilkan pada Tabel 1 yang memperlihatkan bahwa sebagian besar responden dalam penelitian ini berjenis kelamin laki-laki.
Tabel 1. Karakteristik subjek penelitian berdasarkan jenis kelamin dan usia

\begin{tabular}{|c|c|c|c|}
\hline & $\begin{array}{l}\text { kteristik Sampel } \\
\text { Penelitian }\end{array}$ & n $(\%)$ & Rerata \pm SD \\
\hline \multicolumn{4}{|c|}{ Jenis Kelamin } \\
\hline - & Laki-laki & $64(54,7)$ & - \\
\hline- & Perempuan & $53(45,3)$ & \\
\hline \multicolumn{4}{|c|}{ Umur (tahun) } \\
\hline - & 9 & $12(10,3)$ & \multirow{6}{*}{$10,74 \pm 1,045$} \\
\hline - & 10 & $38(32,5)$ & \\
\hline- & 11 & $43(36,8)$ & \\
\hline- & 12 & $19(16,2)$ & \\
\hline - & 13 & $3(2,6)$ & \\
\hline- & 14 & $2(1,7)$ & \\
\hline
\end{tabular}

Tabel 1 juga menggambarkan usia responden berkisar antara 9-14 tahun dengan rerata usia 10,74 $(S D=1,045)$ tahun dan usia paling banyak adalah 11 tahun.

Tabel 2. Frekuensi tingkat ansietas

\begin{tabular}{cccccccr}
\hline & \multicolumn{7}{c}{ Tingkat Ansietas } \\
\cline { 2 - 7 } & \multicolumn{2}{c}{ Normal } & \multicolumn{2}{c}{ Ringan } & \multicolumn{2}{c}{ Sedang } & Berat \\
\cline { 2 - 8 } & f & \% & f & \% & f & \% & \\
\hline $\begin{array}{c}\text { SDN 02 } \\
\text { Ulak }\end{array}$ & 34 & 68 & 7 & 14 & 8 & 16 & 2 \\
$\begin{array}{c}\text { Karang } \\
\text { Selatan }\end{array}$ & & & & & & & \\
\hline $\begin{array}{c}\text { SDN 33 } \\
\text { Kalumbuk }\end{array}$ & 43 & 64,2 & 16 & 23,9 & 8 & 11,9 & 0 \\
\hline Total & 77 & & & & & & \\
\hline
\end{tabular}

Analisis bivariat untuk melihat hubungan dari masing-masing variabel, baik variabel independen (risiko tsunami) dan variabel dependen (tingkat ansietas) dengan uji chi-square. Hasil uji statistik tidak memenuhi syarat uji chi-square karena terdapat sel yang bernilai nol sehingga dilakukan uji ulang dengan menggabungkan tingkat ansietas sedang dan berat.

Hasil uji chi-square antara risiko tsunami dengan tingkat ansietas pada murid SDN 02 Ulak Karang Selatan dan SDN 33 Kalumbuk dapat dilihat pada Tabel 3. 
Tabel 3. Hasil uji Chi-square antara risiko tsunami dengan tingkat ansietas pada anak-anak di SDN 02 Ulak Karang Selatan (zona merah) dan SDN 33 Kalumbuk (zona Hijau)

\begin{tabular}{cccccccc}
\hline \multirow{2}{*}{$\begin{array}{c}\text { Risiko } \\
\text { Tsunami }\end{array}$} & \multicolumn{2}{c}{ Tingkat Ansietas } & \multirow{2}{*}{ Total } & \multirow{2}{*}{ p } \\
\cline { 2 - 5 } & & & & & & \\
\hline $\begin{array}{c}\text { Zona } \\
\text { merah }\end{array}$ & 7 & 43,75 & 9 & 56,25 & 16 & 100 & \\
Zona & 16 & 66,7 & 8 & 33,3 & 24 & 100 & 0,151 \\
hijau & & & & & & & \\
\hline Total & 23 & 57,5 & 17 & 42,5 & 40 & 100 & \\
\hline
\end{tabular}

Tabel 3 menunjukkan anak-anak yang bersekolah di zona merah lebih banyak menunjukkan gejala ansietas sedang sedangkan anak-anak yang bersekolah di zona hijau lebih banyak menunjukkan gejala ansietas ringan. Hasil uji chi-square menunjukkan bahwa nilai $p=0,151(p<0,05)$ yang artinya tidak ada hubungan yang bermakna antara risiko tsunami terhadap tingkat ansietas pada pada anak-anak di SDN 02 Ulak Karang Selatan (zona merah) dan SDN 33 Kalumbuk (zona hijau).

\section{PEMBAHASAN}

Adanya risiko tsunami sebagai stimulus lingkungan spesifik dapat mencetuskan timbulnya ansietas pada seseorang. Penelitian yang dilakukan oleh Kar et al (2007) terhadap anak-anak dan remaja satu tahun sesudah bencana super-cyclone di Orissa, India, menunjukkan bahwa didapatkan prevalensi gejala psikiatri yang berbeda pada daerah paparan tinggi dengan daerah yang paparannya rendah; perasaan takut bahwa bencana akan datang kembali tercatat prevalensi $60.4 \%$ pada daerah paparan tinggi dan $23.5 \%$ pada daerah paparan rendah; prevalensi depresi $37.3 \%$ pada daerah paparan tinggi dan $14.5 \%$ pada daerah paparan rendah. ${ }^{8}$

Penelitian terhadap kesehatan psikis di Sumatra setelah Tsunami ditunjukkan bahwa ada perbedaan kesehatan psikis setelah kejadian bencana pada masyarakat di daerah dengan kerusakan berat dibandingkan dengan masyarakat di daerah yang tidak secara langsung terkena Tsunami. ${ }^{6}$

Namun dari hasil penelitian ini didapatkan tingkat ansietas anak di zona merah sebesar $14 \%$ anak mengalami gejala ansietas ringan, $16 \%$ ansietas sedang, $2 \%$ ansietas berat serta $68 \%$ anak tidak mengalami gejala ansietas (normal). Sedangkan di zona hijau didapatkan $23,9 \%$ anak mengalami gejala ansietas ringan, 11,9\% ansietas sedang, 64,2\% anak tidak mengalami ansietas serta tidak ditemukan anak yang mengalami gejala ansietas berat. Tidak terdapat perbedaan yang bermakna antara tingkat ansietas anak-anak di zona merah dengan anak-anak di zona hijau. Anamnesis ditemukan bahwa adanya berbagai simulasi yang dilakukan pada anak-anak yang bersekolah di zona merah mengurangi rasa takut terhadap adanya risiko tsunami di sekitar mereka, sehingga menurunkan kejadian ansietas pada anak tersebut. Hal ini sesuai dengan survei yang dilakukan oleh Kaplan et al pada tahun 2011, di Amerika Serikat terhadap mahasiswa keperawatan didapatkan bahwa setelah dilakukan simulasi (an Emergeny Preparedness Disaster Simulation) telah terjadi peningkatan skenario kepercayaan, peningkatan basis pengetahuan, peningkatan kepercayaan bekerja dalam tim, kemampuan untuk menangani situasi darurat dan kesiapsiagaan untuk bekerja lebih efektif di rumah sakit atau klinik. ${ }^{9}$

\section{KESIMPULAN}

Tidak terdapat hubungan yang bermakna antara risiko tsunami dengan tingkat ansietas pada anak-anak di zona merah dan zona hijau.

\section{DAFTAR PUSTAKA}

1. BMKG. Tsunami. 2005 (diunduh 23 Januari 2014). Tersedia dari: URL: HYPERLINK http://www.bmkg. go.id/bmkg pusat/Geofisika/Tsunami.bmkg

2. Hawari D. Pendekatan psikoreligi pada trauma bencana. Jakarta: Fakultas Kedokteran Universitas Indonesia, 2011.

3. Widianti E. Pengaruh terapi logo dan terapi suportif kelompok terhadap ansietas remaja di rumah tahanan dan lembaga permasyarakatan wilayah Provinsi Jawa Barat (tesis). Jakarta: Universitas Indonesia; 2011.

4. Gumairo MS, Steinman M, Kernkraut AM, Santos OFP, Lacerda SS. Psychological distress in survivors of the 2010 Haiti Earthquake. Journal of Proquest. 2013.(11):11-13. 
5. Hartini N. Bencana tsunami dan stres pasca trauma pada anak. Jurnal Masyarakat dan Kebudayaan Politik. 2010

6. Frankenberg E, Friedman J, Gillespie T, Ingwersen $\mathrm{N}$, Pynoos R, Rifai IU, et al. Mental health in sumatra after the tsunami. American Journal of Public Health. 2008. 98(9).

7. McCloskey J, et al. Tsunami threat in Indian Ocean from a future megathrust earthquake West of Sumatera. Journal of Elsevier. 2007. 27(9).
8. Kar N, Mohapatra PK, Nayak KC, Pattanaik P, Swain SP, Kar HC. Post-traumatic stress disorder in children and adolescents one year after a supercyclone in Orissa India. Journal of BMC Psychiatry. 2007.7(8).

9. Kaplan BG, Connor A, Ferranti EP, Holmes L, Spencer $L$. Use of an emergency preparedness disaster simulation with undergraduate nursing students. Journal of NCBI. 2011;29(1):44-51. 
